\title{
コイルドウェーブスプリングのばね特性と応力の実用計算法*
}

\author{
高橋英輝 ${ }^{*}$, 川村直子**，久納孝彦 ${ }^{* *}$
}

\section{A Practical Calculating Method on Spring Characteristics and Stresses of Coiled Wave Springs}

\author{
Hideki TAKAHASHI, Naoko KAWAMURA, Takahiko KUNOH
}

\begin{abstract}
Coiled wave springs (CWS) are considered as multiple layered waved washers. They are light but powerful in limited spaces. In recent years, CWS have been applied to clutches of automobiles and expected to be applied to other uses.

The formulas on the spring rates and stresses of CWS have been presented by an American spring maker of Smalley Steel Ring Company, Nishio, and Japan Spring Manufacturers Association (for short, JSMA). But none of them are practical, because the accuracy is not enough. Moreover the derivations of the formulas are not clear in the case of Smalley and JSMA. It has been observed that CWS show nonlinear spring characteristics in large deflection, however, the cause has not been made clear.

In this research, spring rates and stresses for CWS are analyzed theoretically. A cause of the nonlinear spring characteristics is made clear, too. Then empirical formulas on the spring rates and stresses are derived by comparing the theoretical results with experiments and FEM analysis.
\end{abstract}

Key Words: Coiled wave spring, Nonlinear spring, Spring characteristics, Stress analysis, FEM analysis

\section{1. 緒言}

コイルドウェーブスプリング（以下CWS）は，波形座金 を多重巻きにしたもので, 構造が単純で軽量, かつ少ない スペースで強力なばね力が得られる特徵を有する (Fig. 1). 近年, CWSは自動車のクラッチ用部品として採用され1), 今後もその用途の拡大が考えられることから，その特性の 解明が望まれている。

CWSのばね定数及び応力の計算式は，Smalley社 ${ }^{2)}$ ，西尾

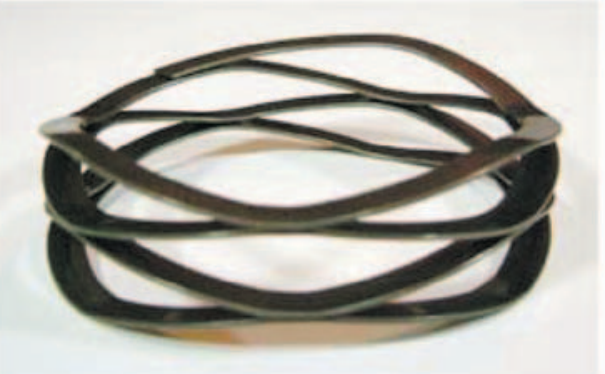

Fig.1 Coiled wave spring (CWS)
$ら^{33)}$ 4)，及び，日本ばね工業会（以下JSMA） ${ }^{5)}$ にっって発表 されている。しかし，これらには導出過程が不明，式が複 雑, 精度が不十分といった問題がある。また，CWSのばね 特性はたわみの増加とともに，非線形性を示すが，そのメ カニズムは十分には解明されていない6(7),8).

そこで，本研究では，CWSのばね定数及び応力を理論的 に解析し，CWSが非線形ばね特性を示すメカニズムを解明 するとともに，その結果を実駼並びにFEM解析結果と比較 して,ばね定数及び応力についての実用計算式を導くこと を目的とする。

\section{2. 主な記号と単位}

\begin{tabular}{cl} 
寸法形状関連 \\
\hline$b$ & $:$ 素線の幅 \\
$t$ & $:$ 素線の厚さ \\
$D$ & $:$ コイル平均径 \\
$R$ & $:$ コイル平均半径
\end{tabular}

$[\mathrm{mm}]$ $[\mathrm{mm}]$ $[\mathrm{mm}]$ $[\mathrm{mm}]$

\footnotetext{
原稿受付日 2005年12月8日

*日本ばね学会2005年度春季講演会にて発表

** 慶應義塾大学 (Keio University)
} 


$\begin{array}{llr}I D & : \text { コイル内径 } & {[\mathrm{mm}]} \\ O D & : \text { コイル外径 } & {[\mathrm{mm}]} \\ H & : \text { 自由高さ } & {[\mathrm{mm}]} \\ h & : \text { 1巻当たりの自由高さ }(=H / n-t) & {[\mathrm{mm}]} \\ N & : \text { 1巻当たりの山数 } & \\ n & \text { : 有効巻数 } & \\ l & \text { : 波形を構成する直線部の長さの } 1 / 2 \quad \text { (Fig. 6参照) } \\ & & {[\mathrm{mm}]} \\ r & \text { : 波形を構成する円弧部の曲率半径 } & \text { (Fig. 6参照) }\end{array}$

$[\mathrm{mm}]$

$\phi$ : 波形を構成する円弧部の中心角 (Fig. 6参照)

$\alpha \quad$ : 任意のコイル中心角 (Fig. 5参照)

$\beta$ : 山と谷のなすコイル中心角 $(=2 \pi / 2 N)$

$[\mathrm{rad}]$

[rad]

$[\mathrm{rad}]$

荷重，たわみ，ばね定数及び応力関連

\begin{tabular}{|c|c|c|}
\hline$P$ & ：軸荷重 & {$[\mathrm{N}]$} \\
\hline$p$ & : 波形素線1山当たりの軸荷重 $(=P / N)$ & {$[\mathrm{N}]$} \\
\hline$M_{b}$ & : 曲げモーメント & {$[\mathrm{N} \cdot \mathrm{mm}]$} \\
\hline$M_{t}$ & :ねじりモーメント & {$[\mathrm{N} \cdot \mathrm{mm}]$} \\
\hline$I$ & : 断面二次モーメント & {$\left[\mathrm{mm}^{4}\right]$} \\
\hline$Z$ & : 曲げの断面係数 & {$\left[\mathrm{mm}^{3}\right]$} \\
\hline$J$ & : サンブナンのねじり定数9) & {$\left[\mathrm{mm}^{4}\right]$} \\
\hline$U_{b}$ & : 素線1/4山分の曲げひずみエネルギー & {$[\mathrm{N} \cdot \mathrm{mm}]$} \\
\hline$U_{t}$ & : 素線1/4山分のねじりひずみエネルギー & {$[\mathrm{N} \cdot \mathrm{mm}]$} \\
\hline$\delta$ & : CWS全体のたわみ & {$[\mathrm{mm}]$} \\
\hline$\delta_{b}$ & ：曲げによる素線1/4山分のたわみ & {$[\mathrm{mm}]$} \\
\hline$\delta_{B}$ & ：曲げによる素線1山分のたわみ & {$[\mathrm{mm}]$} \\
\hline$\delta_{t}$ & : ねじりによる素線 $1 / 4$ 山分のたわみ & {$[\mathrm{mm}]$} \\
\hline$\delta_{T}$ & ：ねじりによる素線1山分のたわみ & {$[\mathrm{mm}]$} \\
\hline$k$ & : ばね定数 ～～～～～～～～ & {$[\mathrm{N} / \mathrm{mm}]$} \\
\hline$k_{\max }$ & : 大たわみ時のばね定数 & {$[\mathrm{N} / \mathrm{mm}]$} \\
\hline$k_{\min }$ & : 小たわみ時のばね定数 & {$[\mathrm{N} / \mathrm{mm}]$} \\
\hline$\sigma_{1}$ & ：最大主応力 & {$[\mathrm{MPa}]$} \\
\hline$\sigma_{1 \max }$ & ：修正最大主応力 & {$[\mathrm{MPa}]$} \\
\hline$\sigma_{b}$ & ：最大曲げ応力 & {$[\mathrm{MPa}]$} \\
\hline$\tau_{t}$ & ：最大ねじり応力 & {$[\mathrm{MPa}]$} \\
\hline$k_{s}$ & :ひずみゲージのゲージ率 & \\
\hline$\varepsilon_{a, b, c}$ & ：ロゼットゲージで測定された3方向の垂 & 直ひずみ \\
\hline
\end{tabular}

\section{1 ばね定数計算式}

\subsection{1 既存のばね定数計算式}

本研究で取り扱うCWSの外観をFig. 2に，それらの仕様を Table 1にそれぞれ示す。

CWSのばね定数についての代表的な計算式をTable 2に示 す. Table 2中のJSMA規格については訂正式を示す。これら の計算式によるば特性をCWS 1について比較すると Fig. 3 のようになり，西尾の計算式及びJSMA規格の訂正式による 值は実験值から大きくずれることがわかる。一方，Smalley 社の計算式による值は実験值とよく合っているが，後述の ように仕様によっては実験值からずれるものもある。また， Smalley社の計算式とJSMA規格の訂正式は導出過程が不明

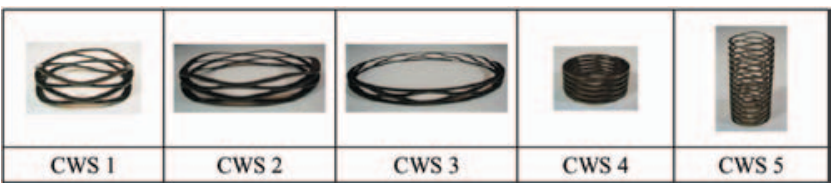

Fig.2 Test springs

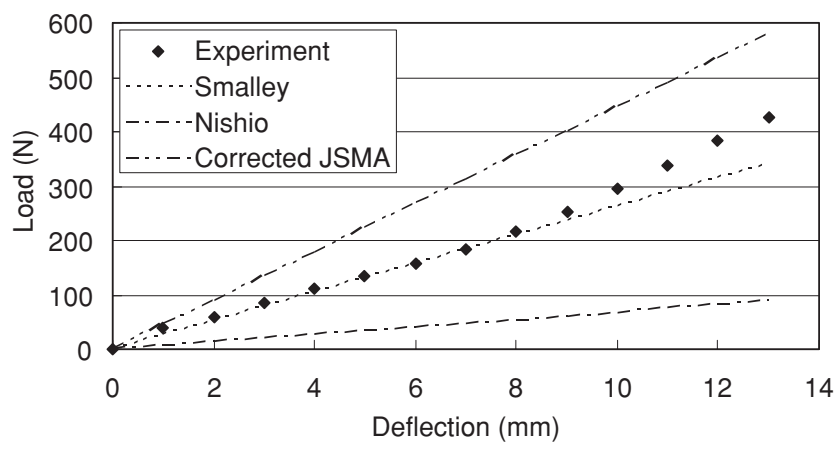

Fig.3 Load-deflection diagram (CWS 1)

Table 1 Specification of test springs

\begin{tabular}{|l|c|c|c|c|c|}
\hline Test spring No. & 1 & 2 & 3 & 4 & 5 \\
\hline Material of CWS & \multicolumn{3}{|c|}{$\begin{array}{c}\text { High carbon steel wire } \\
\text { (SWRH) }\end{array}$} & \multicolumn{2}{|c|}{$\begin{array}{c}\text { Stainless steel } \\
\text { (SUS304) }\end{array}$} \\
\hline Young's modulus $E(\mathrm{GPa})$ & \multicolumn{3}{|c|}{206} & \multicolumn{2}{|c|}{186} \\
\hline Shear modulus $G(\mathrm{GPa})$ & \multicolumn{3}{|c|}{78} & \multicolumn{3}{|c|}{69} \\
\hline Width $b(\mathrm{~mm})$ & 5.42 & 7.96 & 6.75 & 1.995 & 1.669 \\
\hline Thickness $t(\mathrm{~mm})$ & 0.854 & 1.147 & 0.664 & 0.335 & 0.316 \\
\hline Mean diameter of coil $D(\mathrm{~mm})$ & 67.11 & 132.72 & 185.20 & 21.03 & 22.24 \\
\hline Free length $H(\mathrm{~mm})$ & 21.21 & 20.33 & 11.46 & 8.65 & 46.60 \\
\hline Number of waves / turn $N$ & 3.5 & 5.5 & 9.5 & 3.5 & 3.5 \\
\hline Active coils $n$ & 4 & 4 & 2 & 9 & 28 \\
\hline
\end{tabular}

Table 2 Formulas on spring rates and stresses of CWS

\begin{tabular}{|c|c|c|}
\hline Proposer & Spring rate & Stress \\
\hline Smalley $y^{2)}$ & $k=\frac{E b t^{3} N^{4}}{\lambda n D^{3}} \frac{O D}{I D}$ & $\sigma_{b}=\frac{3 \pi D}{4 b t^{2} N^{2}} P$ \\
\hline Nishio ${ }^{3,4}$ & $\begin{array}{r}N / n\left[\frac{\cos ^{2} \phi}{2 E I}\left\{\frac{l^{3}}{3}+3 l^{2} r \phi+4 l r^{2}(1-\cos \phi)\right.\right. \\
\left.\left.+\frac{r^{3}(2 \phi-\sin 2 \phi)}{4}\right\}+\frac{2 R^{3}(\beta-\sin \beta)}{G . J}\right]\end{array}$ & $\begin{array}{l}\sigma_{b}=\frac{3 D \sin \beta}{2 b t^{2} N} P \\
\tau_{t}=\frac{D(1-\cos \beta)}{4 \kappa b t^{2} N} P \\
\sigma_{1}=\frac{\sigma_{b}}{2}+\sqrt{\frac{\sigma_{b}^{2}}{4}+\tau_{t}^{2}}\end{array}$ \\
\hline $\begin{array}{l}\text { Corrected } \\
\text { JSMA }^{5}\end{array}$ & $k=\frac{16 E b t^{3} N^{4}}{\pi^{3} n D^{3}}$ & $\sigma_{b}=\frac{3 \pi D}{4 b t^{2} N^{2}} P$ \\
\hline
\end{tabular}


である。導出過程が明らかにされている西尾の計算式音を 再検討したものには, 川村の研究 ${ }^{11)}$ があるが，その後の検 討で十分な修正ではないことがわかったので，さらに見直 すことにした。

\subsection{2 西尾式の訂正と実用式化}

本研究では, 西尾のばね定数計算式の導出過程, 川村に よる修正過程を再検討し, それらの誤りを以下のように訂 正する。

\section{（a）波形素線の形状と曲げたわみ}

5 種類の供試CWS素線の波形曲線を平面展開した結果, それらがほぼ円弧と直線で構成されていることがわかった。 この波形平面曲線は対称性を有するので, Fig. 4のように 1/4山を平面展開した片持はりについてたわみ解析を行う. すなわち, 荷重 $p / 2$ にるはりの直線部及び円弧部に作用 する曲げモーメント $M_{b 1}, M_{b 2}$ はそれぞれ

$M_{b 1}=\frac{p}{2} \cos \phi \cdot x$

$M_{b 2}=\frac{p}{2}\{\cos \phi \cdot(l+r \sin \theta)+r \sin \phi \cdot(1-\cos \theta)\}$

となる.これらによる素線の曲げひずみエネルギー $U_{b 1}, U_{b 2}$ はそれぞれ

$U_{b 1}=\frac{1}{2 E I} \int_{0}^{l} M_{b 1}^{2} d x=\frac{p^{2} l^{3} \cos ^{2} \phi}{24 E I}$

$U_{b 2}=\frac{1}{2 E I} \int_{0}^{\phi} M_{b 2}^{2} r d \theta$

$=\frac{p^{2} r}{8 E I}\left\{(l \cos \phi+r \sin \phi)^{2} \phi+2 r(l \cos \phi+r \sin \phi)(\cos \phi-1)\right.$

$$
\left.+\frac{r^{2}(2 \phi-\sin 2 \phi)}{4}\right\}
$$

となり, Fig. 4で荷重方向のたわみを $\delta_{b 1}, \delta_{b 2}$ とすると, カ スチリアーノの定理により，

$$
\begin{aligned}
& \delta_{b 1}=\frac{\partial U_{b 1}}{\partial(p / 2)}=\frac{p l^{3} \cos ^{2} \phi}{6 E I} \\
& \delta_{b 2}=\frac{\partial U_{b 2}}{\partial(p / 2)} \\
& =\frac{p r}{2 E I}\left\{(l \cos \phi+r \sin \phi)^{2} \phi+2 r(l \cos \phi+r \sin \phi)(\cos \phi-1)\right. \\
& \left.+\frac{r^{2}(2 \phi-\sin 2 \phi)}{4}\right\}
\end{aligned}
$$

したがって，曲げによる素線1山分のたわみ $\delta_{B}$ は

$$
\begin{aligned}
\delta_{B}= & 2\left(\delta_{b 1}+\delta_{b 2}\right) \\
= & \frac{p r}{E I}\left\{\frac{l^{3}+\cos ^{2} \phi}{3} r \phi(l \cos \phi+r \sin \phi)^{2} \phi+2 r^{2}(l \cos \phi+r \sin \phi)\right. \\
& \left.(\cos \phi-1)+\frac{r^{3}(2 \phi-\sin 2 \phi)}{4}\right\} \cdots \cdots \cdots \cdots \cdots \cdots \cdots(7)
\end{aligned}
$$

\section{（b）波形素線のねじりによるたわみ}

Fig. 5のように，素線を面外荷重荷重 $p / 2$ を受ける円弧は りとみなし，CWSのねじりによるたわみを解析する。

荷重 $p / 2$ にり Fig. 5に示す円弧はりに作用するねじりモ ーメント $M_{t}$ は,

$M_{t}=\frac{p}{2} R(1-\cos \alpha)$

であるから，素線のねじりひずみエネルギーU $U_{t}$ は，

$U_{b 1}=\frac{1}{2 G J} \int_{0}^{\beta / 2} M_{t}^{2} \cdot R d \alpha=\frac{p^{2} R^{3}}{8 G J}\left(\frac{3}{4} \beta-2 \sin \frac{\beta}{2}+\frac{\sin \beta}{4}\right) \cdots(9)$

ただし，Jはサンブナンのねじり定数"9) であり，

$J=b t^{3}\left(\frac{1}{3}-\frac{64}{\pi^{5}} \frac{t}{b} \tanh \frac{\pi b}{2 t}\right)$

と表される。

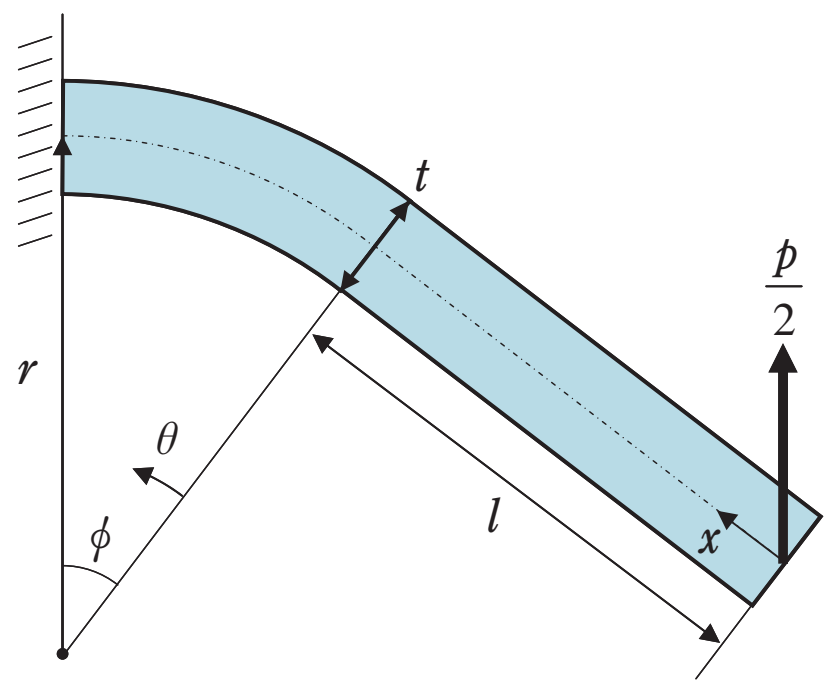

Fig.4 Plane bending of $1 / 4$ wave segment

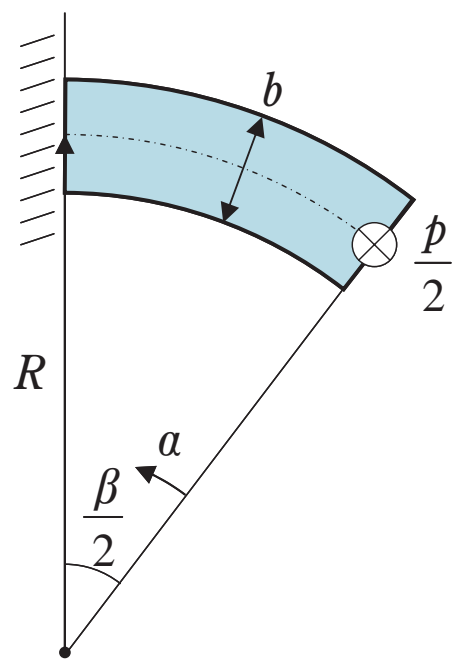

Fig.5 Torsion of $1 / 4$ wave segment 
Fig. 5で荷重方向のたわみを $\delta_{t}$ とすると，カスチリアーノ の定理により，

$\delta_{t}=\frac{\partial U_{t}}{\partial(p / 2)}=\frac{p R^{3}}{2 G J}\left(\frac{3}{4} \beta-2 \sin \frac{\beta}{2}+\frac{\sin \beta}{4}\right)$

したがって，ねじりによる素線1山分のたわみ $\delta \gamma は$

$\delta_{T}=2 \delta_{t}=\frac{p R^{3}}{G J}\left(\frac{3}{4} \beta-2 \sin \frac{\beta}{2}+\frac{\sin \beta}{4}\right)$

で与えられる。

(c) 西尾訂正式

式 (7)，(12）より，CWS全体のたわみ $\delta$ は

$\delta=n \cdot\left(\delta_{B}+\delta_{T}\right)$

となる。また, CWS全体の荷重 $P$ は,

$P=N \cdot p$

となる。以上より，ばね定数計算式は，

$k=\frac{P}{\delta}=\frac{N \cdot p}{n \cdot\left(\delta_{B}+\delta_{T}\right)}$

$$
\begin{aligned}
=N / n[ & \frac{1}{E I}\left\{\frac{l^{3} \cos ^{2} \phi}{3}+r \phi(l \cos \phi+r \sin \phi)^{2}\right. \\
& \left.+2 r^{2}(l \cos \phi+r \sin \phi)(\cos \phi-1)+\frac{r^{2}(2 \phi-\sin 2 \phi)}{4}\right\} \\
& \left.+\frac{R^{3}}{G J}\left(\frac{3}{4} \beta-2 \sin \frac{\beta}{2}+\frac{\sin \beta}{4}\right)\right] \ldots \ldots \ldots \ldots \ldots \ldots \ldots
\end{aligned}
$$

で与えられる。

\section{(d) 西尾訂正式の実用式化}

式（15）に含まれる変数 $\phi, l, r$ Fig. 6のような波形素 線の平面展開図を前提としており，実測が難しい。また， 式（15）は複雑で使いにくい。そこで，式（15）の実用性 を考慮し，その近似式を導いた。

まず，波形形状を表す変数 $\phi, l, r$ のち，lは $\phi$ と $r$ の 関数として表現できる.すなわち, Fig. 6の素線中心線の投 影長さと $\beta$ の関係 $2 r \sin \phi+2 l \cos \phi=R \beta$ より，

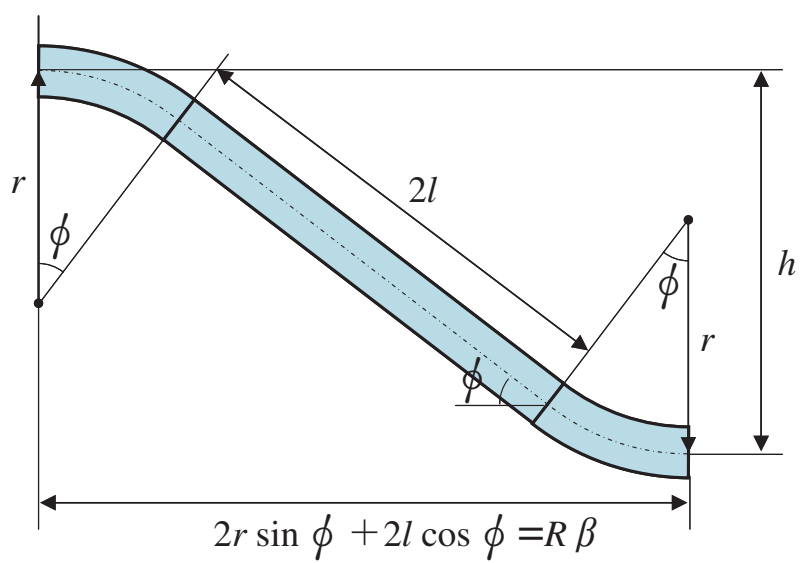

Fig.6 1/2 wave segment in plane
$l=\frac{R \beta-2 r \sin \phi}{2 \cos \phi}$

となる。また，実用に供されているCWSでは фが十分に小 さいので, $\phi \approx 0$ とみなせば, $\cos \phi$ と $\sin \phi$ は

$\cos \phi \approx 1, \quad \sin \phi \approx 0$

と近似することができる。この近似は，Fig. 4に示す波形は りを真直はりとみなすことを意味する。式（16）と式（17） を式（15）に代入し，さらに，曲げによる項に比べ十分小 さいねじりによる項を無視すれば，ばね定数近似式（18） が得られる。

$k \approx N / n\left[\frac{1}{E I}\left\{\left(\frac{R \beta-2 r \sin \phi}{2 \cos \phi}\right)^{3} \frac{\cos ^{2} \phi}{3}\right\}\right]$

$\approx N / \frac{n}{E I} \cdot \frac{R^{3} \beta^{3}}{24}$

$=\frac{192 E I N^{4}}{\pi^{3} n D^{3}}$

$=\frac{16 E b t^{3} N^{4}}{\pi^{3} n D^{3}}$

これはJSMA規格の訂正計算式（Table 2参照）と一致する.

\section{2 応力計算式}

\section{2 .1 既存の応力計算式}

CWSの応力についての代表的な計算式をTable 2 に示す. Table 2中のJSMA規格については訂正式を示す。一例として CWS 1を取り上げ，これらの計算式による応力の計算結果 を比較するとFig. 7のようになる.

Table 2より, Smalley社の計算式とJSMA規格の訂正式は 導出過程が不明であるが同一で，最大曲げ応力を対象とし ている。これに対し，西尾の計算式は最大主応力を評価対 象としている。また，Fig. 7の実験結果は最大主応力の測定 結果を示す．Fig. 7より，Smalley社の計算式及びJSMA規格 の訂正式による值は実験結果より低い值を与える。一方, 西尾の計算式による值は安全側にはあるが，荷重が大きく なると精度は十分でないことがわかる。

\section{2 .2 応力計算式の導出}

\section{(a) 最大曲げ応力式}

最大曲げ応力はFig. 4において, $\theta=\phi$ の断面で発生し,

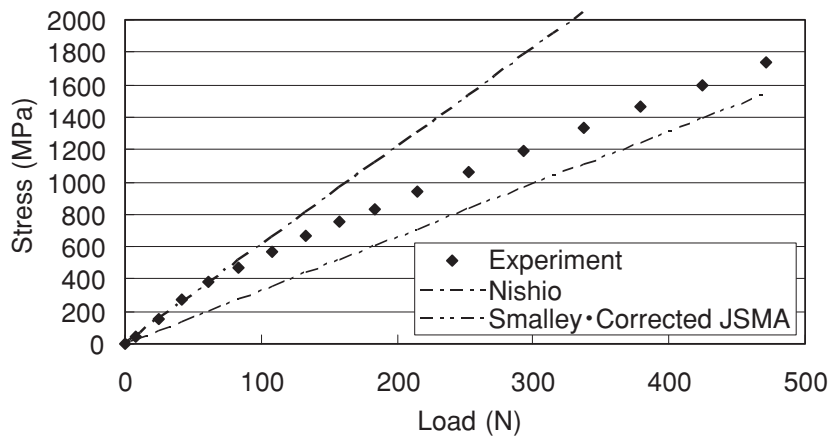

Fig.7 Stress - Load diagram (CWS 1) 
この断面に作用する曲げモーメント $M_{b}$ は, 式 (2) より

$M_{b}=\frac{p}{2}\{\cos \phi(l+r \sin \phi)+r \sin \phi \cdot(1-\cos \phi)\}$

$=\frac{p}{2}(l \cos \phi+r \sin \phi)$

となる.よって，最大曲げ応力 $\sigma_{b}$ は

$\sigma_{b}=\frac{M_{b}}{Z}=\frac{3(l \cos \phi+r \sin \phi)}{b t^{2} N} P$

となる。また, Fig. 6より, 式中の $\phi, l, r$ をと $\beta$ で表せ ば

$\sigma_{b}=\frac{3 P \cdot \frac{R \beta}{2}}{b t^{2} N}=\frac{3 \pi D}{4 b t^{2} N^{2}} P$

と書き換えられる。これはSmalley社の計算式及びJSMA規 格の訂正計算式（Table 2参照）と一致する.

\section{(b) 最大ねじり応力式}

最大ねじり応力はFig. 5において, $\alpha=\beta / 2$ の断面で発生 し, この断面に作用するねじりモーメント $M_{t}$ は, 式 (8) より

$M_{t}=\frac{p}{2} R\left(1-\cos \frac{\beta}{2}\right)$

となる.よって, 最大ねじり応力 $\tau_{t}$ は

$\tau_{t}=\frac{1}{\kappa} \cdot \frac{M_{t}}{b t^{2}}=\frac{P D(1-\cos (\beta / 2))}{4 \kappa b t^{2} N}$

となる。

しかし，CWSには主として曲げ応力が発生し，最大ねじ り応力は, 最大曲げ応力に比べ十分小さいので, 最大主応 力 $\sigma_{1}$ は

$\sigma_{1}=\frac{\sigma_{b}}{2}+\sqrt{\frac{\sigma_{b}^{2}}{4}+\tau_{t}^{2}} \approx \sigma_{b}$

となり, 実際の応力評価では最大曲げ応力のみを考えれば よく, 応力計算式 (25) が得られる.

$\sigma_{1} \approx \sigma_{b}=\frac{3 \pi D}{4 b t^{2} N^{2}} P$

\section{4. 実 験}

\section{1 ばね特性の測定}

ばね試験機（豊光エンジニアリング社製 HTC-A20K型） を用い，5種類の供試コイルドウェーブスプリングCWS 1 5をコイル軸方向に平行圧縮して，荷重とたわみを測定した。

\section{2 応力測定}

ひずみゲージ : 共和電業社製KFG-1-120-D17-11L1M2

$\left(0^{\circ} / 45^{\circ} / 90^{\circ}\right.$ 形3軸ロゼットゲージ $)$

グリッド寸法 $1 \times 1.1 \mathrm{~mm}$, ベース寸法 $\phi 5 \mathrm{~mm}$

抵抗值 $120 \Omega$, ゲージ率 $k_{s} 2.1$
接 着 剂：共和電業社製CC-33A

動ひずみ計：共和電業社製UCAM-20PC, 制御ソフトウェアUCS10A

CWS 1〜3の波形素線谷部にロゼットゲージを貼付し，ば ね試験機で密着荷重付近まで平行圧縮して，荷重と3軸方向 のひずみ $\varepsilon_{a}, \varepsilon_{b}, \varepsilon_{c}$ を測定した。そして，ひずみ測定結果 から次式により主応力 $\sigma_{1}$ とその方向 $\psi$ を求めた ${ }^{12}$. なお, CWS 4及びCWS 5については素線幅が小さく，ひずみゲー ジが貼れなかったため，応力測定は行っていない.

$$
\begin{aligned}
\sigma_{1}= & \frac{E}{2\left(1-\nu^{2}\right)}\left[(1+\nu)\left(\varepsilon_{a}+\varepsilon_{c}\right)\right. \\
& \left.+(1-\nu) \sqrt{2\left\{\left(\varepsilon_{a}-\varepsilon_{b}\right)^{2}+\left(\varepsilon_{b}-\varepsilon_{c}\right)^{2}\right\}}\right] \\
\psi= & \frac{1}{2} \tan ^{-1}\left(\frac{2 \varepsilon_{b}-\varepsilon_{a}-\varepsilon_{c}}{\varepsilon_{a}-\varepsilon_{c}}\right) \ldots \ldots \ldots \ldots \ldots
\end{aligned}
$$

\section{FEM解析}

・使用ソフト：MARC MENTAT 2005r2

・使用要素：20節点アイソパラメトリック任意形状6面体 要素 ${ }^{13}$

・解析モデル :

Fig. 8参照. CWS 1, CWS 2は4巻モデル, CWS 3は2巻 モデル. CWS 4, CWS 5は4巻モデルで，各たわみをそれ ぞれ9/4倍，7倍して供試CWSと同じたわみ量になるよう にした。後述のように, Fig. 8（a）は素線の山と谷の接 触状態が線接触（Linear contact）, Fig. 8（b）は点接触 (Point contact) するモデルである.

- 要素分割：

素線の幅方向に3等分割，厚さ方向に 2 等分割，円周方 向に180等分割した。

- 境界条件：

解析モデル両端面のコイル軸まわりの回転を拘束し、

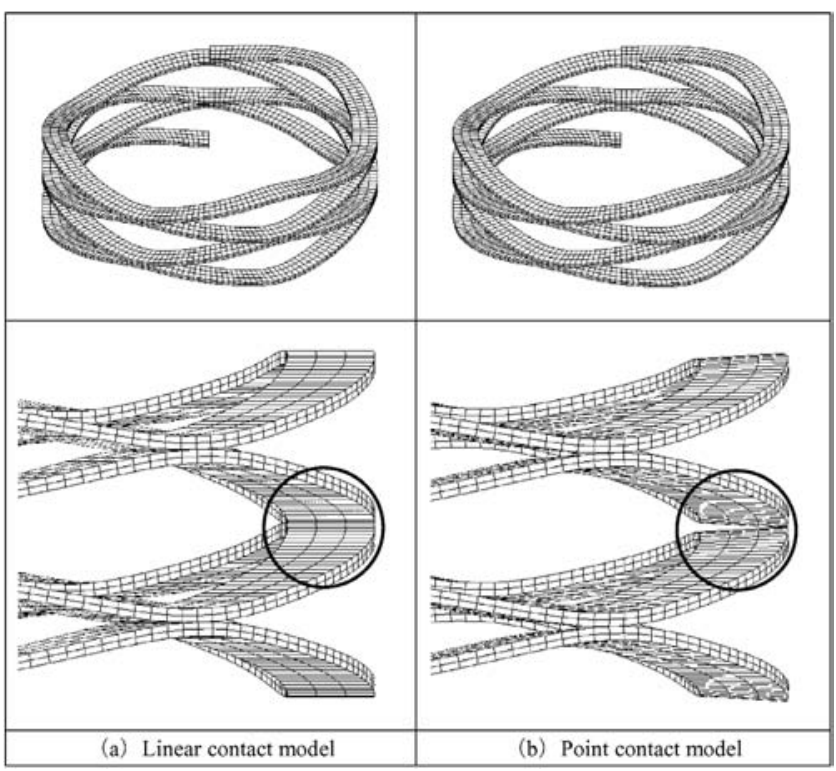

Fig.8 FEM analysis models 
両座面と接するように定義した2枚の剛体平板により CWSモデルをコイル軸方向に平行圧縮した（Fig. 9)。 な お，剛体平板と素線の接触，及び素線同士の接触が生じ た場合には摩擦力（摩擦係数 0.2 のクーロン摩擦）を考慮 した。

\section{6. 解析結果と考察}

\section{1 ばね特性}

供試CWS 1〜5のばね特性について，理論解析結果及び実 験結果, FEM解析結果を図示すると, Fig. 10のようになる。 素線間の接触がLinear contactな場合, ばね特性のFEM解析 結果はたわみの増大とともに，傾きが一定となる傾向を示 し，その值は理論解析結果とほぼ一致する。

一方，荷重に対するたわみ量を比較すると，理論解析結 果とLinear contactを仮定した場合のFEM解析結果は実験結 果と大きく異なる。DRAGONIは波形座金の素線が一般に傾 いていることを指摘し，ばね特性への影響を論じている ${ }^{14}$. 本研究で取り扱った供試CWSに抒いてもFig. 11に示すよう に無荷重時に素線の山と谷部の素線断面が互いに逆方向に 傾いて成形されているため, 初期接触状態ではLinear contactではなく，Point contactとなっていることがわかった (Fig. 11)。そこで，素線の山と谷の接触状態が点接触とな るようなFEM解析モデル (Fig. 8 (b)) を作り，上記の解析 結果と比較した。Fig. 10より，FEM解析結果はLinear contactの場合よりも，Point contactの場合の方がたわみが大 きくなり，実験結果とよく合うことがわかる。また，負荷 にともなうPoint contactモデルの変形挙動を観察すると, 素 線の山と谷部の断面の傾きが徐々に減少し，ある荷重点で 山と谷の接触状態がPoint contactからLinear contactへと変化 するまでばね特性はほぼ直線で表される。一方，Linear contactな場合にもばね特性は，直線となり，その傾きは式 （18）で与えられる。また，Point contact時のばね定数はFig. 12に示すようにLinear contact時のばね定数のおよそ $0.5 \sim 0.6$ 倍となる。これらを考慮すれば非線形ばね特性は1本の折れ 線で表され，各々の直線は次の実用ばね定数計算式で表す ことができる.

$\kappa_{\max }=\frac{16 E b t^{3} N^{4}}{\pi^{3} n D^{3}}$

$\kappa_{\min }=\gamma_{1} \frac{16 E b t^{3} N^{4}}{\pi^{3} n D^{3}}\left(\gamma_{1}=0.5 \sim 0.6\right)$

この接触状態の変化とばね定数の変化の関係は実験におい ても確認された。

さらに, Point contactから Linear contactへ変化する屈曲点 はCWS 1，CWS 4，CWS 5では全たわみの打よそ50\%， CWS 2, CWS 3では全たわみの拈よそ35\%となる。屈曲点 の現れる点は1卷当たりの山数 $N$ とコイル平均径 $D$ に依存し,

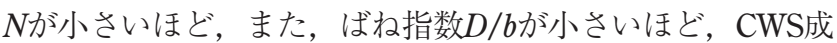
形時の素線断面の倒れが大きくなり，ばね特性への影響が 増す傾向が認められる。

\section{2 応 力}

供試CWS 1 5の応力について, 理論解析結果及び実験結 果，FEM解析結果をFig. 10に示す．FEM解析による最大主 応力分布はFig. 13のようになり, 波形素線の谷部表面の内 径側で最大主応力は大きくなっている。一方，Linear contactモデルとPoint contactモデルにおいて最大主応力分布 に大きな違いは無く，波形素線の谷部表面の内径側をFEM 解析値とした。

Fig. 10をみると， Linear contactモデルとPoint contactモデ ルによる最大主応力のFEM解析結果はほぼ一致し，実駼結 果とも比較的よく合うことがわかる。一方，理論解析結果 は実験結果やFEM解析結果よりも低い值を示すが，これは 理論解析で素線のねじり応力を無視していること，CWS素

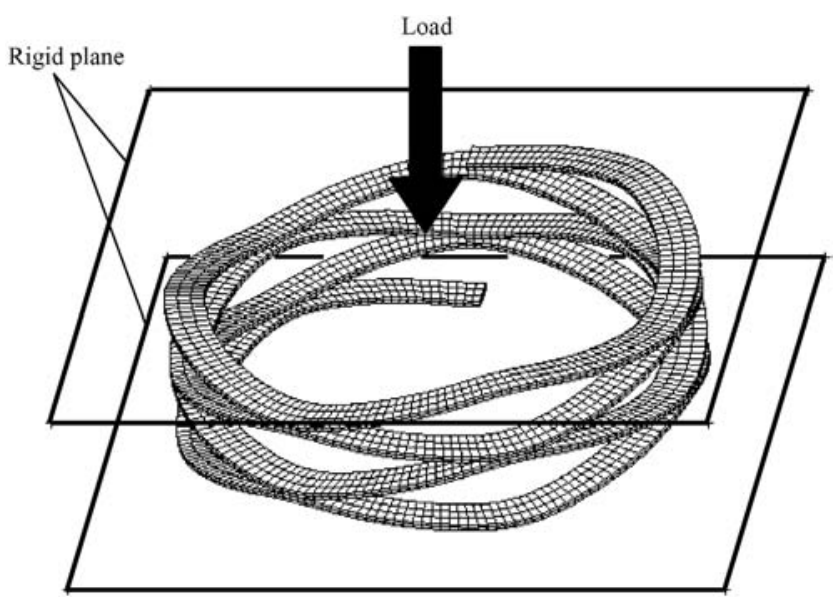

Fig.9 Loading and constraint condition of FEM analysis model

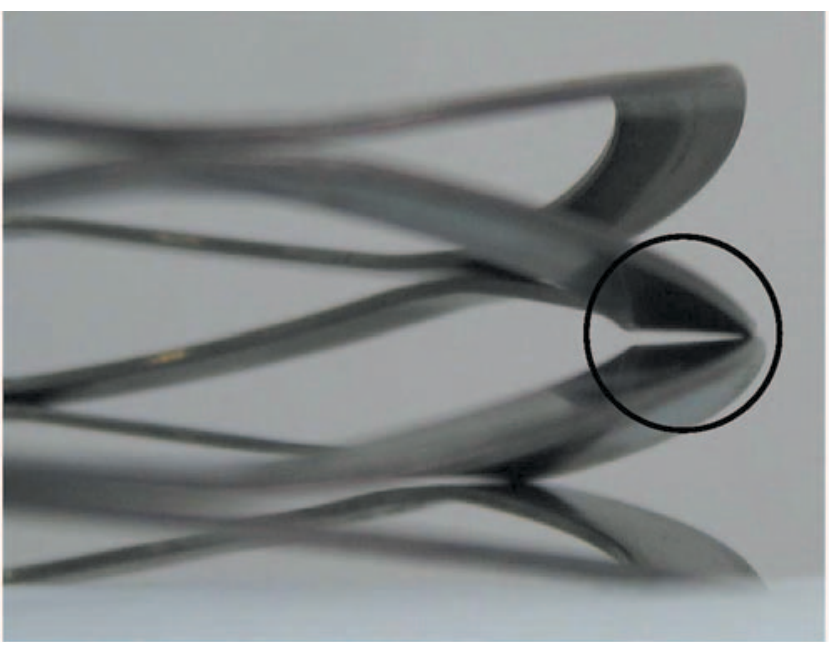

Fig.11 Point contact of CWS

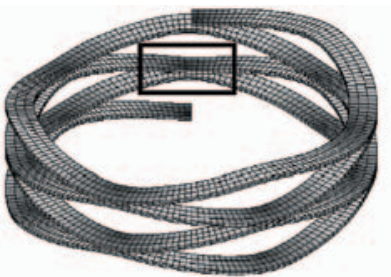

(a) Whole view

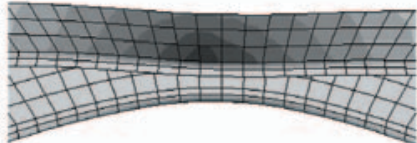

(b) Close up view near contact point
Fig.13 Distribution of maximum principal stress 

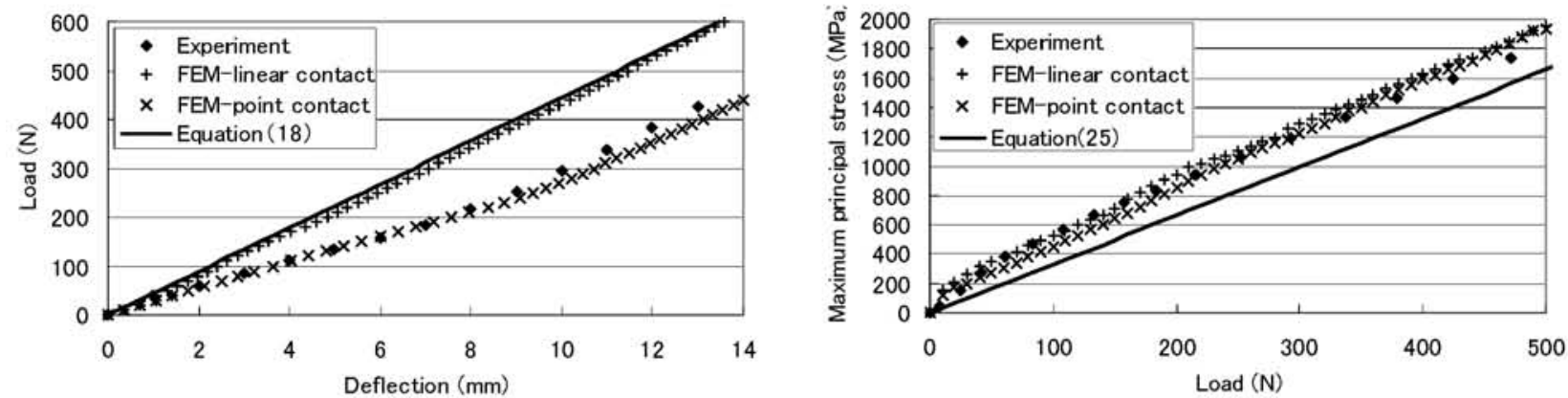

CWS 1
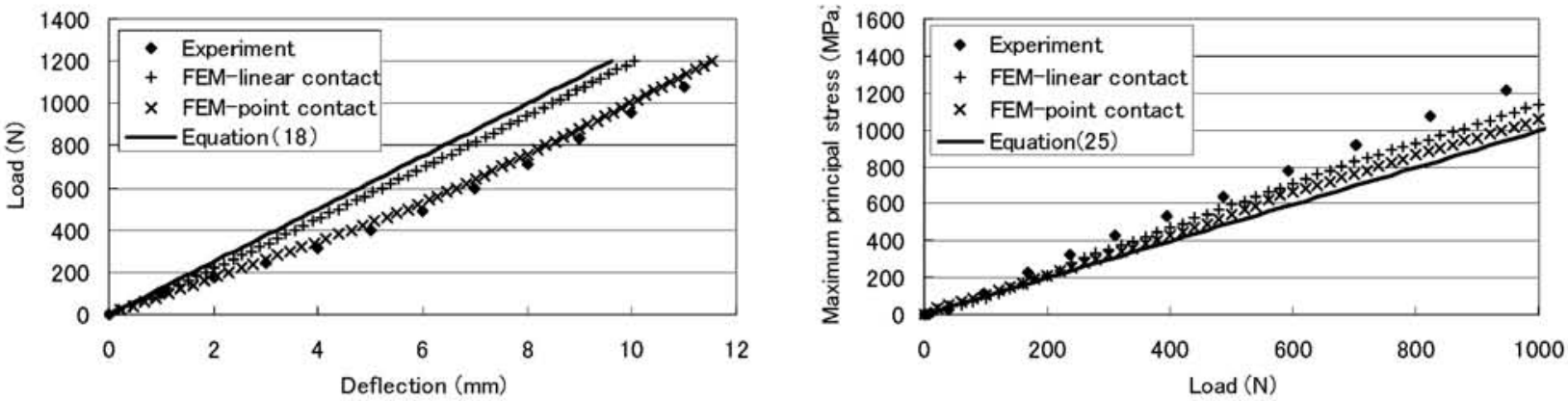

CWS 2
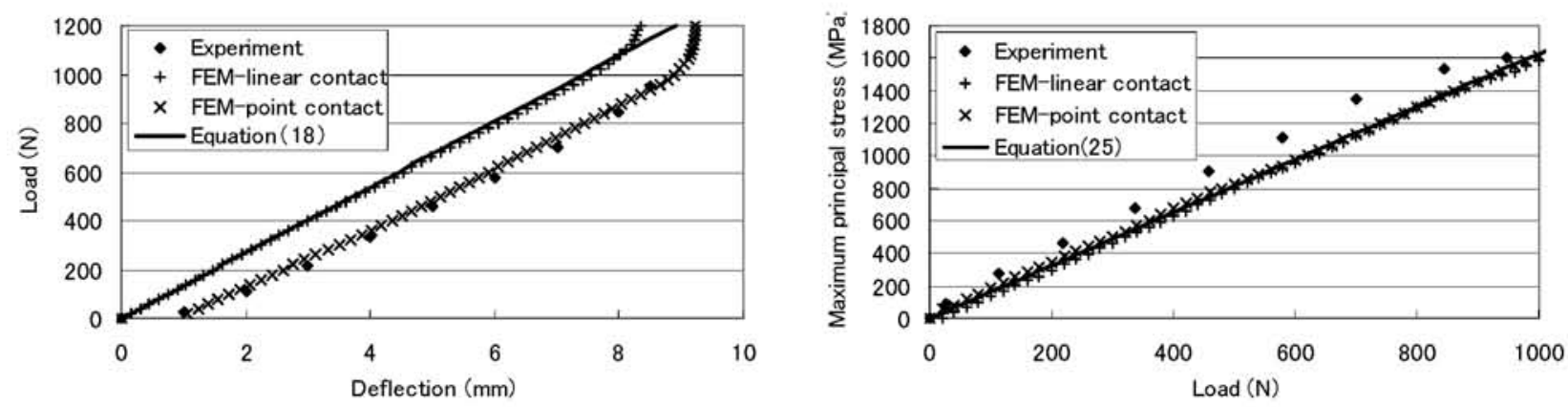

CWS 3
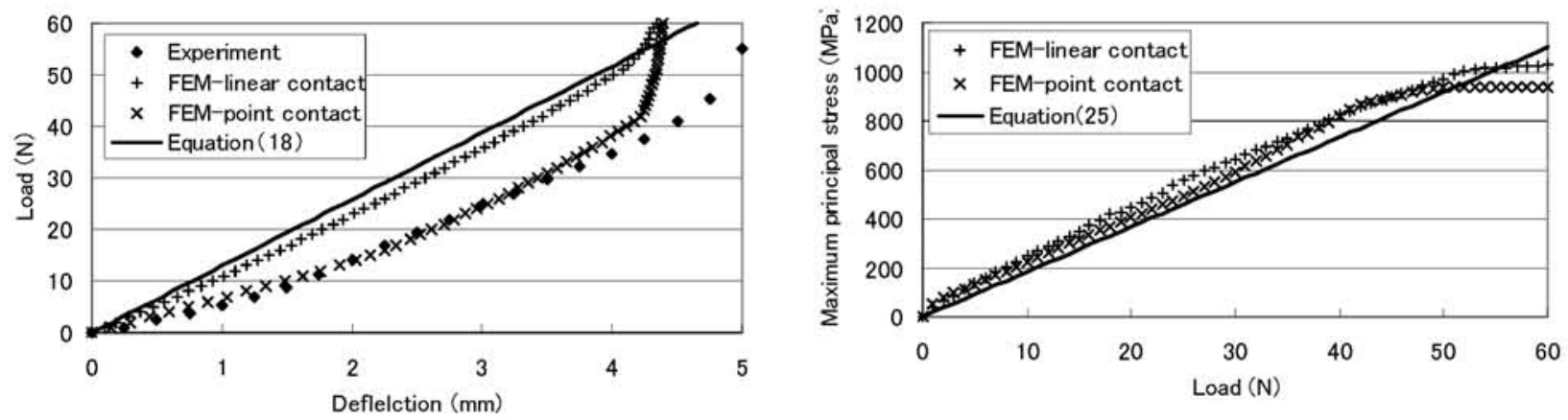

CWS 4
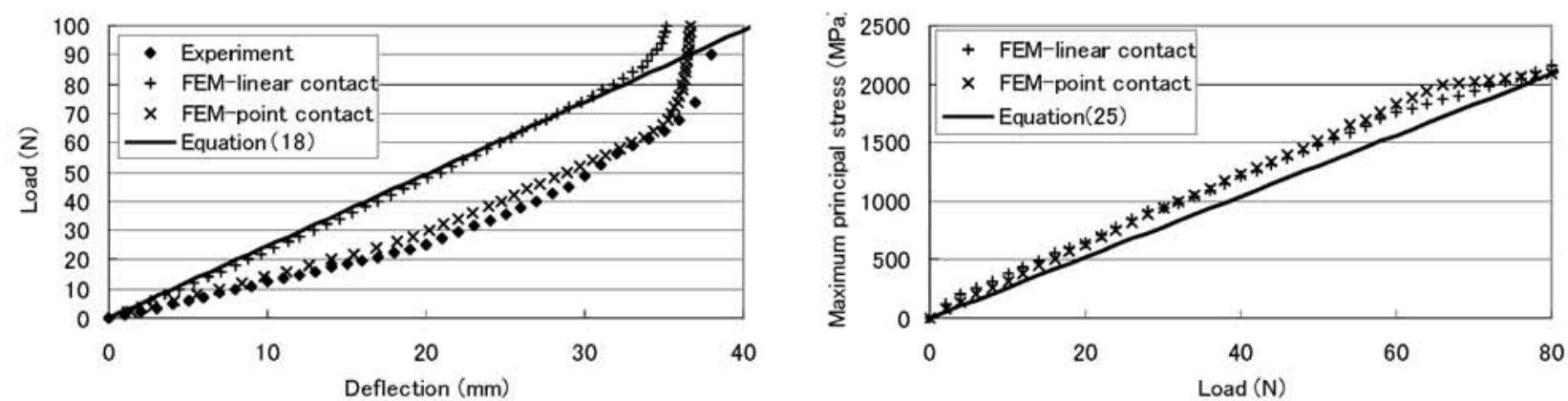

CWS 5

Fig.10 Spring characteristics and stresses of CWS 

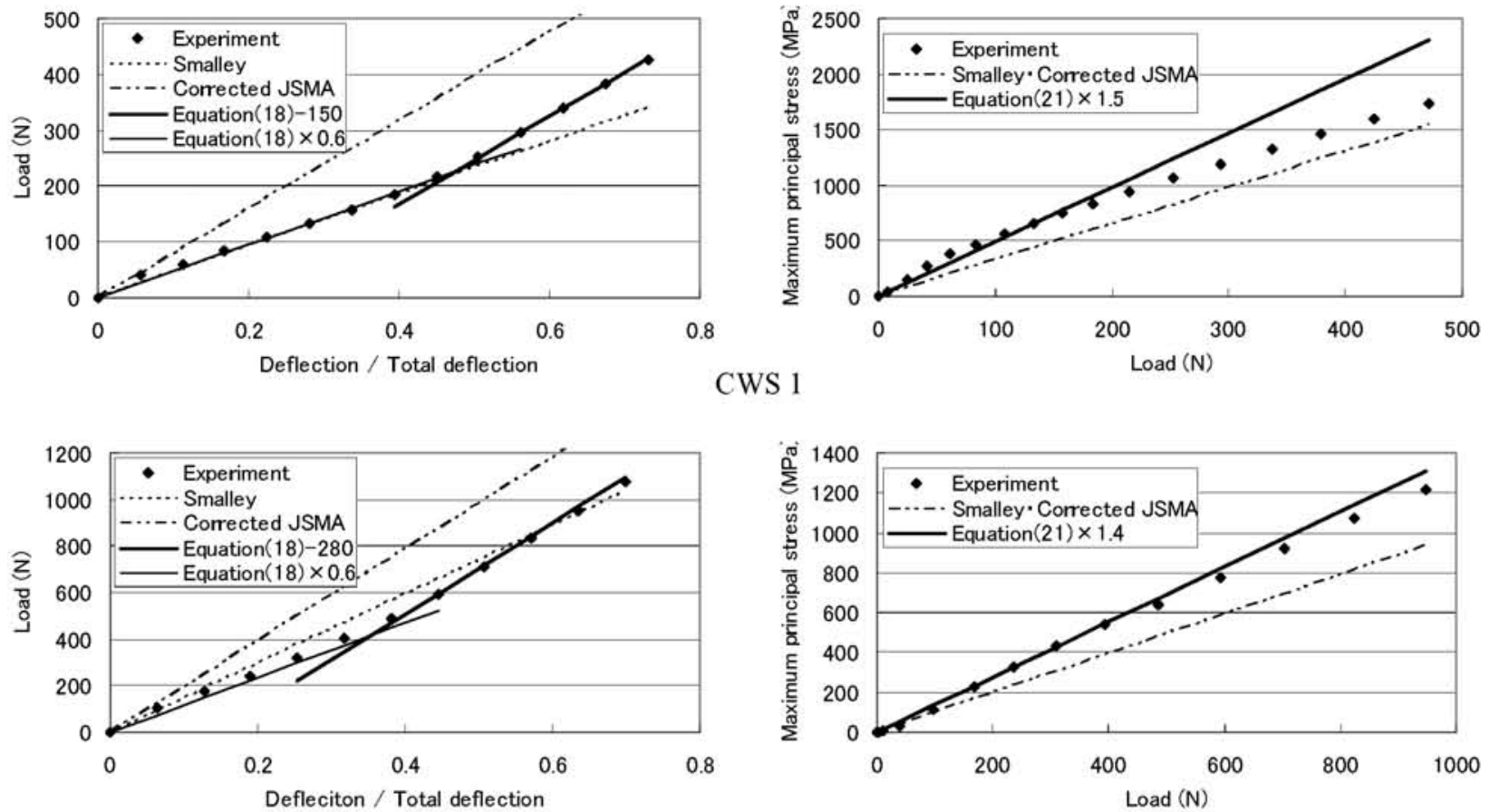

CWS 2
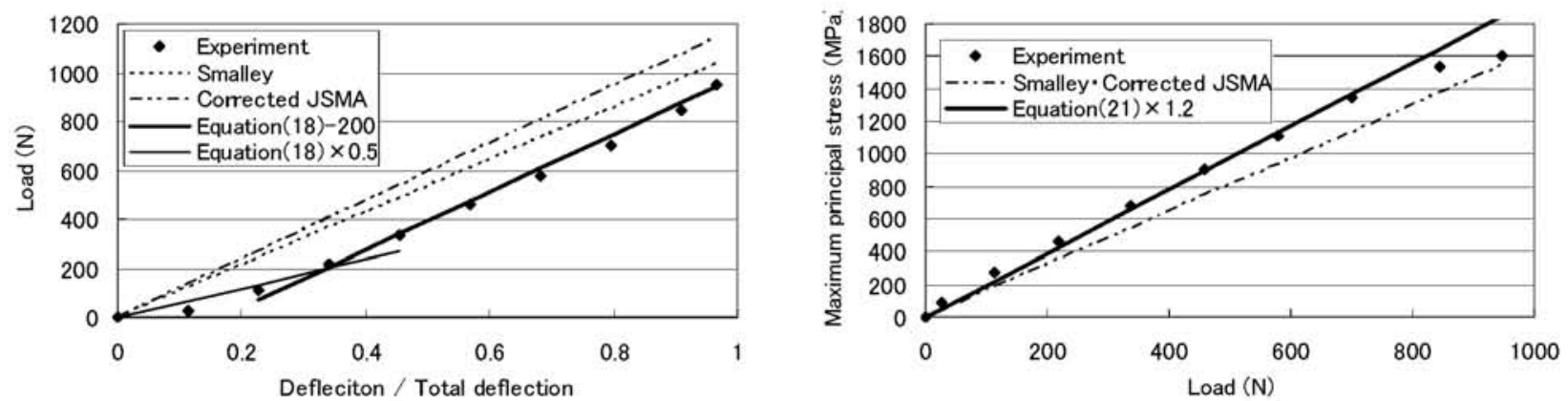

CWS 3
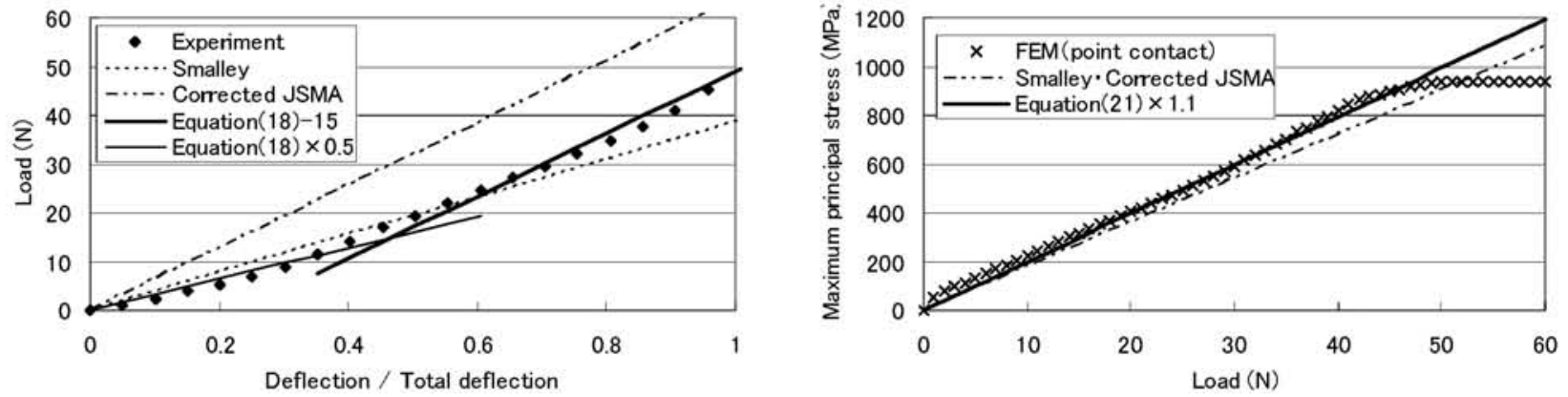

CWS 4
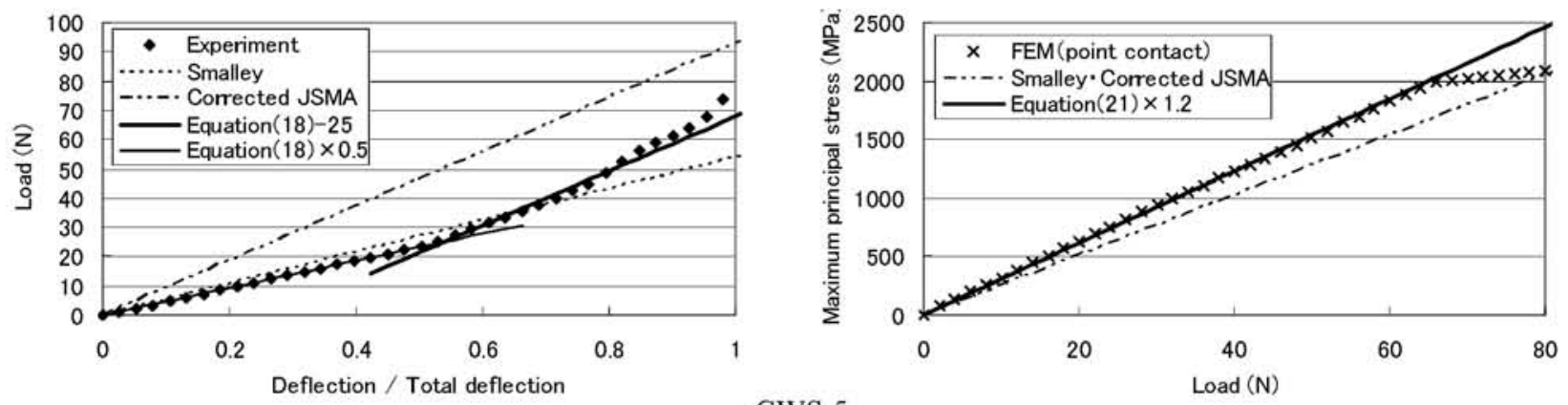

CWS 5

Fig.12 Formulas on spring rates and stresses of CWS 
線を平面展開して応力解析していることなどによると考え られる。そこで, 実用応力計算式を導くために理論解析結 果に修正係数 $\gamma_{2}$ を掛け, 応力值が実験值を下回らないよう に補正してみると Fig. 12のようになり，修正係数の值は1.1 〜 1.5 となる.

$\sigma_{1 \max }=\gamma_{2} \frac{3 \pi D}{4 b t^{2} N^{2}} P\left(\gamma_{2}=1.1 \sim 1.5\right)$

\section{7. 結 言}

以上，CWSのばね特性の非線形性の原因が解明され，実 用計算法が示された。 また，応力特性についても実用計算 法が明らかにされた。すなわち

\section{ばね特性について}

CWSの非線形ばね特性は凹形の折れ線で近似することが でき，その原因は圧縮にともなう素線の山部と谷部の接触 状態が点接触から線接触へと変化するためであることが確 かめられ，実用ばね定数計算式が示された。

\section{応力について}

CWSには主として曲げ応力が発生し, 最大主応力は波形 素線の谷部の表面の内径側で最大となる。また, 最大主応 力の值は荷重の大きさに比例して変化する. 理論応力計算 式による值を実験結果と比較することにより修正した実用 応力計算式が示された。

\section{謝辞}

本研究を進めるに当たり有益な御助言を頂いた三菱製鋼 (株下関正義氏，CWSの使用状況並びに規格化について御教 示頂いた(株パイオラックスの東海林信義氏，高 良昭氏，ば ね特性並びに応力測定実験に御協力頂いた(株)多摩スプリン グの渡辺浩太郎氏に深甚の謝意を表します。また，FEM解 析に協力頂いた本学学部生の村上圭吾君に謝意を表します。

\section{参考文献}

1）ばね技術研究会編，“ばねの種類と用途例”，(1998) pp.82-83, 日刊工業新聞社.

2) Smalley Steel Ring Company, Wave/Compression Springs, Catalog No.WS-2002， (2002), pp.27-30.

3）西尾康宏, 渡辺浩太郎, 久納孝彦, ばね論文集, No.47, (2002), pp.15-20.

4）ばね技術研究会編，“ばねの設計と製造・信頼性”, (2001)，pp.17-19，日刊工業新聞社

5）JSMA SB009, (2004), pp.1-4, 日本ばね工業会.

6）川村直子, 西尾康宏, 渡辺浩太郎, 久納孝彦, ば ね技術研究会2001年度秋季講演会講演論文集, (2001), pp.31-34.

7）青木功, 大梘敦巳, 日本機械学会東海支部第 52 期 総会講演会講演論文集，No.033-1，（2003），pp.257258.

8）木村雅幸, 加藤万規男, 大澤一紀, 和田均, 日本 機械学会東海支部第53期総会講演会講演論文集, No.043-1, (2004), pp.51-52.

9) Wang C.T., “応用弾性学”, (1974), pp.101-105, 森北出版.

10）鵜戸口英善，川田雄一，倉西正嗣，“材料力学 上 巻”, (1983), pp.110-111, 裳華房.

11）川村直子，慶應義塾大学修士論文，(2003), pp.1422

12) Budynas Richard G., "Advanced Strength and Applied Stress Analysis”, (1977), pp.362-366, McGRAW-HILL KOGAKUSHA.

13）ばね技術研究会編，“ばねの有限要素解析”，(1997） pp.67-68, 日刊工業新聞社.

14) DRAGONI E., Journal of Strain Analysis for Engineering Design, 23-3 (1988), pp.145-153. 